\title{
Life-purpose aspects of value formation in the context of personality becoming
}

\author{
Alexander A. Ozerov ${ }^{1,2^{*}}$ \\ ${ }^{1}$ Financial University under the Government of the Russian Federation, Department of Humanities, \\ Moscow, Russia \\ ${ }^{2}$ Federal State Public Military Educational Institution of Higher Education "Military University" of \\ Ministry of Defence of the Russian Federation, Moscow, Russia
}

\begin{abstract}
The article is devoted to the value dimension problem when searching for the meaning of life in the past and present. Considering the pedagogical aspect of the problem, the authors have carried out an analysis of existing life-purpose convictions, as well as the possibility of solving existential problems and crisis developments of the Russian social medium. The authors suggest ways to improve the state of Russian society, taking into account the peculiarities of personal development and value formation. Throughout human history, life has served as the highest universal value. Human gives life its own specific meaning, whereas the general meaning of life is to gain experience through the natural laws of the very life, or from absolute values being beyond life. At first glance, this approach seems correct; however, a detailed study reveals several shortcomings in this approach. In the pursuit of pleasure and profit, a person is transformed from a free implementer of his desires into a slave of his desires. Focusing on pleasure often ends up destroying the psyche and the body. It is worth noting that the consideration of a human as a means to achieve higher goals devalues human life. For the sake of absolute ideas, which are usually illusions, a human becomes subjected to religious or political fanaticism.

Keywords: philosophy, culture, the meaning of life, history, society, pedagogy.
\end{abstract}

\section{Introduction}

Currently, the problem of the meaning of existence is the most acute in Russia. Numerous statistical data from the psychological, social, pedagogical, and philosophical sciences indicate that man of today is characterized by the experience of acute existential vacuum. Often there is a lack of meaningfulness of reality, the emptiness of existence. Consider the value component of the meaning of life.

The concerned problem is revealed in the axiological dimension of the individual's existence, as well as in the very process of searching for the reason for existence.

During the historical process, a human has long been in search of comprehending the reason for his existence, in a kind of self-knowledge, considering his own attitude to the

\footnotetext{
* Corresponding author: aaozerov@,fa.ru
} 
outside world and the people around him. In each epoch, questions of the reason for the existence of the world, of a human, of world processes in common were arising before his consciousness in various forms. For example, O. Khayyam in his poem notes that there is an endless circle in which there is no way to find the end and the beginning, and the role of a person is only to "come and go" [1]. According to the poet, in this context, it is extremely difficult to find any meaning at all.

In the system of the spiritual world of society, the main goal is moral education, building a harmonious personality, parenting a sense of patriotism and citizenship, developing the ability to competently find solutions to the problems of the social formation, finding the most demanded vectors for creating an axiological component of the socio-humanitarian constituent of contemporary Russia [2].

Real facts, phenomena, and objects are not only recognized and processed in the minds of people, contributing to the education and formation of a sense of belonging, delight, affection but also contribute to the appearance of negative emotions.

The important role of values in the framework of philosophy and pedagogy is characterized by the state of axiology and the contribution of adherents of neo-Kantianism, namely, H. Rickert, and W. Windelband, as well as supporters of the Marburg philosophy, E. Cassirer and P. Natorp. Consider them in more detail.

Rickert proceeds from the idea that the world around was formed from reality (initially, the integral vital activity of a human), as well as from "a completely independent kingdom lying beyond subject and object" [3]. The consideration of the latter as a certain phenomenon reflects the desire to realize and form the nonsubjective nature of values, the peculiarities of the manifestation of their autonomy, due to taste, habits, upbringing, education, awareness, and other criteria. By nature, values are phenomena whose inner essence lies in their importance for the individual and society rather than in their facticity.

Cassirer, on the contrary, was sure that the values of the individual were the very process of choice that individuals made when considering the values of society [4]. According to Cassirer, a person is constantly in search of his individual self which feels the existentialism of internal and external reality. It is necessary to emphasize that in this case, the level of socialization and the degree of education of the individual are of no small importance. If they are insufficient, a high level of awareness of life-meaning categories may be inaccessible to an ill-mannered and morally undeveloped person. The tools of contemporary pedagogy are of great importance since they can be used to increase the degree of life-purpose awareness of the individual, to strengthen his sense of conscience and justice. In this regard, an important role is played by the values as such, which are instilled in the individual in the course of his formation as a person.

The unity of the subjective and objective sides of the inner essence of value comprehension can also be considered at the level of autonomy from the subject, the absence of subordination of value relations to the laws of the society development. Considering the nature of values, one can conclude that in the course of transitions from consumer properties to interest, as well as from intention to value, the significance of the soft issues ${ }^{\dagger}$ increases.

Thus, the concept of value manifests itself in the form of the social essence of the existence of spiritual and material culture. In this regard, the definition of value is closely related to the definition of culture and can be revealed through objects or phenomena of spiritual and material reality. Values are one of the characteristic features of human life, and therefore they are given considerable attention by scientists from all over the world.

\footnotetext{
$\dagger$ The soft issues are the human issues - the fundamental attitudinal or mindset issues of people.
} 


\section{Methods}

Today, there are several types of value theory.

For example, neo-Kantianism considered values as an ideal being. The bearer of such an idea was the transcendental subject.

The objective nature of values was justified using personalistic ontologism in $\mathrm{M}$. Scheller's system of views.

The proponents of naturalistic psychologism of J. Dewey, A. Meinong considered values as objective factors of the world that were understood empirically.

The existence of a large number of value-based equal systems was justified by representatives of cultural and historical relativism represented by O. Spengler, A.J. Toynbee, and W. Dilthey.

Values are considered within the framework of the sociological value concept, which is represented by interpretative sociology (verstehende soziologie). A huge scientific contribution was made by M. Weber, and F.W. Znaniecki, as well as representatives of the school of structural and functional analysis (E.A. Shils, T. Parsons, C.K. Kluckhohn, etc.), who studied the life-purpose through the prism of social philosophy.

When reviewing the literature on value problem, the following groups of value definitions can be distinguished.

1) Definitions, in which the main emphasis is placed on the possibility of processes, phenomena, and elements of reality to be the means of satisfying the interests and needs of the individual. This view is supported by G. Glezerman, V. Tugarinov, A. Shishkin, E. Podolskaya, and other researchers.

2) Definitions, based on the importance of processes, phenomena, and elements of reality for the life of the social medium subjects, their interests, and needs. Besides, there are two standpoints regarding the significance of values. The first group of authors is represented by V. Vasilenko, S. Anisimov, A. Voronina, O. Drobnitsky, M. Kagan, V. Grechany, and others. They believe that for the individual, values are reflected in the system of the positive or negative significance of phenomena and objects of social medium. The second group of authors is represented by $\mathrm{Yu}$. Granin, S. Popov, A. Korshunov, T. Chakyrov, and others, who believed that value is a positive form of significance.

3). Definitions, in which value is considered as a relation. This idea is shared by $\mathrm{K}$. Lyubutin, L. Arkhangelsky, I. Frolov, A. Kharchev, and others.

4). Definitions, in which values are ideals. This opinion is shared by E. Ilyenkov, O. Bakuradze, V. Sagatovsky, I. Narsky, L. Sagatovskaya, and others.

Social processes, phenomena, and objects of the surrounding world are of special significance only for the individual and society. Art, religion, and customs, as well as the culture in general, play a special role here, as well as the specifics of their assimilation in the mind of the individual in the course of upbringing or educational activities if any.

\section{Results}

Let turn to the consideration of the search features for the meaning of life by a man of today.

First of all, it is worth noting that almost all of his life a person sets goals for himself, many of which he never achieves, although the importance of setting goals, their rationalization, take place already in the course of educating the individual at an early stage.

Values that people embody in their actions can be considered as the meaning of human existence. In the course of his socialization and upbringing and educational process, the individual forms his own value system and his worldview.

In the course of studying the personality specifics in understanding the meaning of life considering the values, it is necessary to have an idea of the historical aspects of this issue, 
namely, of how the problem of the meaning of existence was understood by philosophers of antiquity and later period.

Thus, Socrates saw the meaning of life as philosophizing; in other words, self-knowledge, self-testing [5].

Plato argued that happiness was possible exclusively in the afterlife when the immortal soul became the highest essence of the individual [6].

Aristotle was true to his standpoint that the life-purpose of human activity was happiness, which consisted in the implementation of the human essence, knowledge, and thinking [7]. Activity related to art and scientific work were the qualities that were subject to development if the individual could subdue his passions to reason [8].

The Cynics held the view that the essence of human existence was a virtue, which consisted in the ability to be content with little, to avoid evil, to strive for what made a person free and independent.

As for the views of the Epicureans, life in their understanding was perceived as a thirst for pleasure, which they interpreted not only as sensual pleasure but also as overcoming the fear of the end of existence. According to the Epicureans idea, the ideal was a quiet life, and skepticism [9].

A significant interest lies in the views of the Stoics, whose main essence was deep knowledge, closely related to moral ideals. According to them, virtue was based on living in harmony with nature and the universal mind. Indifference to external stimuli and internal contradictions was the foundation of the Stoics. At present, there is a growing interest in the worldview of the Stoics, and a movement of supporters of neo-Stoicism is being created [10].

Aurelius saw the meaning of life in the search for spiritual phenomena of the divine order. At that, a divine revelation was the dominant form of knowledge of the meaning of life [11].

Kant stated: "Two things fill the mind with ever new and increasing admiration and awe, the more often and steadily we reflect upon them: the starry heavens above me and the moral law within me. I do not seek or conjecture either of them as if they were veiled obscurities or extravagances beyond the horizon of my vision; I see them before me and connect them immediately with the consciousness of my existence" [12].

Hegel expressed his opinion that the main subject of the problematics was the world mind which included the divine power that influenced the creation of the world. According to Hegel's theory, being occupies the entire universe. Besides, a powerful rise at the initial stage was followed by a balance maintained in nature throughout the entire time.

The approach to studying the meaning of existence was based on the need to find a positive understanding of life. James' theory was based on the possibility of creating rather than finding the truth [13]. Setting goals that served for the good to value life were exactly the meaning of existence. The pragmatists could achieve the meaning of existence only through experience.

S.L. Frank in his work "The Meaning of Life" examined the question: "Does life have its meaning and what exactly? ... "The human's desire for love and happiness, tears of emotion at the beauty, reverent thought of the joy of light, illuminating and warming the life - is there any solid ground in human's existence, or is it only a reflection in the possessed human's mind of the vague and blind passion, which possesses insects that deceives us, using as a weapon to save the same meaningless prose of animal life, and dooming us for a brief dream of joy and spiritual completeness to pay with vulgarity, lingering boredom and need for a narrow, everyday, humdrum existence? And the thirst for heroic deeds, selfless service to the good, thirst for death in the name of a great and bright cause - is this something greater and more meaningful than a mysterious but meaningless force that drives a butterfly into the fire?" [14].

Instincts do not control the individual. Unlike the human of the past, traditions do not set tasks to the man of today what he needs to do. Consequently, a clear idea was missed. At the 
latest stage of history, the individual found himself in the conditions of an axiological crisis [15].

Not every meaning of existence implies approval. The content is of great importance. Various deviations from the moral norms governing responsibility, regardless of whether these actions are committed voluntarily or involuntarily, eventually end up immoral and also entail violations of the law [16].

\section{Conclusion}

In the context of science and technology development, as well as the digitalization of the economy, taking measures aimed at improving the health of Russian society is of great importance.

According to the Stoics, the meaning of life is in hard work and productive activity for their benefit and the state's benefit. The parenting of such values in the Russian Federation's younger generation will contribute to the elimination of negative social phenomena, stabilize and consolidate society, and help to resolve existential contradictions.

\section{References}

1. O. Khayyam, The Rubaiyat (LBA, London, 2018)

2. K.A. Tarasov, Kul'tury patriotizma v period Pervoy mirovoy voyny [Cultures of patriotism during the First World War] (EUSP Press, Saint Petersburg, 2020)

3. H. Rickert, Sciences of nature and sciences of culture (Translated from the Second German Edition, edited by S. Hessen) (Obrazovaniye Publishers, Saint Petersburg, 1911)

4. E. Cassirer, Poznaniye i deystvitel'nost' [Knowledge and reality] (Izdatelstvo Urait, Moscow, 2018)

5. Socrates, Ya znayu, chto nichego ne znayu [I know that I know nothing] (AST, Moscow, 2019)

6. Plato, Dialogi. Aforizmy [Dialogues. Aphorisms] (Eksmo, Moscow, 2018)

7. Aristotle, Poetika. Ritorika. O dushe [Poetics. Rhetoric. On the soul] (Mir knigi, Moscow, 2009)

8. Diogenes Laërtius, O zhizni, ucheniyakh I izrecheniyakh znamenitykh filosofov [Lives and Opinions of Eminent Philosophers] (Azbuka, Saint Petersburg, 2019)

9. D.A. Gusev, Antichnyy skeptitsizm v istorii stanovleniya nauchnogo myshleniya [Ancient skepticism in the history of the formation of scientific thinking] (DirektMedia, Moscow, 2013)

10. M.V. Salimgareev, Stoicheskoye naslediye v Rossii [Stoic heritage in Russia] (Kazan National Research Technological University Publishing House, Kazan, 2010)

11. Augustine of Hippo. The Augustine catechism: The ynchiridion on aaith, pope and charity (New City Press, New York, 2008)

12. I. Kant, Critique of practical reason (CreateSpace Independent Publishing Platform, Scotts Valley, California, 2010)

13. A.E. Machekhin (Ed.), V poiskakh smysla. Mudrost' tysyacheletiy [In search of meaning. The wisdom of the millennia] (Olma-Press, Moscow, 2002)

14. S.L. Frank, Smysl zhizni [The meaning of life] (Nauka, Moscow, 1992) 
15. N.A. Orekhovskaya, A.G. Tyurikov, P.V. Razov, M.V. Kibakin, N.I. Kiseleva, Eurasian Journal of Analytical Chemistry, 12(7b), 1283-1289 (2017)

16. E.O. Wilson, The meaning of human existence (Liveright Publishing, New York, 2014) 